\title{
TURNING WATER INTO WINE, BEEF AND VEGETABLES: Material Transformations along the Brisbane River
}

\section{Transforming Cultures eJournal, \\ Vol. 1 No. 2, June 2006 \\ http://epress.lib.uts.edu.au/journals/TfC}

\author{
Professor Veronica Strang \\ Department of Anthropology \\ University of Auckland
}

\begin{abstract}
The Brisbane River starts high in the Jimna Ranges in a network of small streams that are often no more than a thread of green in the dusty hills. By the time it reaches the Port of Brisbane, it has been captured, used and turned into many things: beef and vegetables, fruit and wine - things that can be bundled into containers and shipped to the trading partners on which Australia relies.

This paper is concerned with the transformations through which 'natural' resources are acculturated and commodified, in the process becoming not only economic resources, but also material expressions of human agency and identity. As the most basic and most vital ingredient of all organic products, water can 'become' almost anything. It is therefore, like money, broadly perceived as an abstract symbol of wealth and power, defining the relationships between those who have access to and control of water, and the wider populations whose material needs they supply.
\end{abstract}

In Queensland, as in other parts of Australia, there are growing political and economic tensions between rural communities and the enlarging urban populations who now compete for increasingly scarce water resources while also demanding that environmental health should not be sacrificed for economic gains. The implications of this shift have been severe: farmers who formerly enjoyed a primary social and economic position as 'primary producers' now feel beleaguered, undervalued, and resentful of the loss of control implied in newly competitive water allocation processes. A wider shift from farming into residential development or recreational use of land is also reframing Australia's economic relationships with other countries, introducing new forms of 'productivity' and empowering different groups of people. This paper considers how these changing patterns of commodification are changing the social and cultural landscape along the Brisbane River. 


\section{Introduction}

This paper is concerned with the process through which natural resources are commodified and how, through a series of events, they are literally and metaphorically transformed into a wide variety of artefacts. It also considers the relationship between this process of transformation and its potential to empower or disempower particular groups of people.

The discussion is located in a specific ethnographic context, the Brisbane River catchment area in south Queensland, but it is useful, first, to consider the theoretical context in which this work is situated. There are several key areas to consider. One is the way that the self is constructed physically, emotionally and intellectually. ${ }^{1}$ Water is a vital part of this process, being the only material aspect of the environment that everyone, without exception, has to ingest and incorporate. It forms a major part of the constitution of the self, as well as every other organic object, linking people to the material environment, and to each other. As noted elsewhere ${ }^{2}$ it is therefore, both physically and symbolically, a vital connective fluid, encoded with powerful meanings as a source of life and health, and generative ability. It is also widely regarded - for reasons that this paper will make plain - as an iconic symbol of wealth and status.

The reality of the human need to scoop up, imbibe and incorporate water also provides a useful analogy of the way in which people, in a Hegelian dialectic of cognition, project themselves into the world, bring that projection back into themselves and integrate it, thus constituting their own body of knowledge and understanding. ${ }^{3}$ The process of projecting the self - one's identity - into a material environment is also integral to the process through which people gain agency and power, expressing themselves in social and material terms.

\footnotetext{
${ }^{1}$ As outlined, for example by Lupton, D. (1996) Food, the Body and the Self, London, Thousand Oaks, New Delhi: Sage Publications; Caplan, P. (1997) (ed.) Food, Health and Identity, London, New York: Routledge; Howes, D. (2003) Sensual Relations: engaging the senses in culture and social theory, Ann Arbor: University of Michigan Press.

${ }^{2}$ Strang (2004) The Meaning of Water, Oxford, New York: Berg.

${ }^{3}$ Hegel, F. (1977) The Phenomenology of Spirit, Oxford: Clarendon Press; Shore, B. (1996) Culture in Mind: cognition, culture and the problem of meaning, New York, Oxford: Oxford University Press.
} 
As we have learned from writers such as Turner and Schechner ${ }^{4}$ physical and often ritualised action, and the investment of time and labour, constructs literally meaningful links between humans and the material environment that is the dialectical 'other' in humanenvironmental interaction. Humans encode meaning in the surrounding landscape ${ }^{5}$ and in the material objects within it. ${ }^{6}$ They project their identity into this environment, and feel that both it, and themselves, can be polluted by invasions of 'otherness'. At a material level, as Gell observed, ${ }^{8}$ objects become 'prosthetic' extensions of human agency, and as I have argued previously ${ }^{9}$ there is no real dividing line in this respect between the production of material culture, and the acculturation of material aspects of the 'natural' environment. All can be utilised to express identity and social agency ${ }^{10}$ and commodified to produce economic and political power. ${ }^{11}$ As the most vital of resources, water is also the most contested in this respect. ${ }^{12}$

\footnotetext{
${ }^{4}$ Turner, V. (1982) From Ritual to Theatre: the human seriousness of play. New York: Performing Arts Journal Publications; Schechner, R. (1985) Between Theatre and Anthropology, Philadelphia: University of Pennsylvania Press.

${ }^{5}$ Bender, B. (ed.) (1993) Landscape, politics and perspectives, Oxford: Berg; Tilley, C. (1994) A Phenomenology of Landscape: places, paths and monument, Oxford, Providence: Berg; Strang, V. (1997) Uncommon Ground; cultural landscapes and environmental values, Oxford, New York: Berg; Stewart, P. \& Strathern, A. (eds.) (2003) Landscape, Memory and History, London: Pluto Press.

${ }^{6}$ Appadurai, A. (1986) The Social Life of Things, Cambridge: Cambridge University Press; Csikzentmihalyi, M. \& Rochberg-Halton, E. (1981) The Meaning of Things: domestic symbols and the self, Cambridge, Cambridge University Press; Strang, V. (1999) "Familiar Forms: Homologues, Culture and Gender in Northern Australia", Journal of the Royal Anthropological Society, 5(1):75-95; Tilley (ed.) (1999) Metaphor and Material Culture, Oxford: Blackwell.

${ }^{7}$ Douglas, M. (1975) Implicit Meanings: essays in anthropology, London, Boston, Melbourne and Henley: Routledge and Kegan Paul; Durkheim, É. (1995 [1912]) The Elementary Forms of the Religious Life, trans. K. Fields, New York: Free Press.

${ }^{8}$ Gell, A. (1998) Art and Agency: an anthropological theory, Oxford: Clarendon Press.

${ }^{9}$ Strang (2005a) "Knowing Me, Knowing You: Aboriginal and Euro-Australian Concepts of Nature as Self and Other", World Views: Environment, Culture, Religion, 9(1): 25-56.

${ }^{10}$ Lansing, S. (1991) Priests and Programmers: technologies of power in the engineered landscape of Bali. Princeton, New Jersey: Princeton University Press.

${ }^{11}$ Carrier, J. (1995) Gifts and Commodities, London: Routledge; Kopytoff, I. (1986) "The Cultural Biography of Things: commoditization as process" in A. Appadurai (ed) The Social Life of Things: commodities in cultural perspective, Cambridge: Cambridge University Press; Miller, D. (1998) (ed.) Material Cultures: why some things matter, London: UCL Press.

${ }^{12}$ Blatter, J. \& Ingram, H. (2001) (eds.) Reflections on Water: new approaches to transboundary conflicts and cooperation, Cambridge, Mass., London: MIT Press; Ward, C. (1997) Reflected in Water: a crisis in social responsibility, London and Washington: Cassell; Strang, V. (2004).
} 
There is thus a multi-layered relationship between the control of material objects and the degree of agency and influence that people have, and it is not difficult to appreciate why the ownership and control of physical resources such as water form the basis of wealth and status. A detailed ethnographic approach allows us to consider how this happens. How is water transformed? How does this process provide power and status? And why is water particularly important in this respect?

The research from which this paper arises, which is being done in collaboration with Sandy Toussaint at UWA, is concerned with several Australian river catchments, including the Brisbane River, where I have been conducting fieldwork over the last three years. This is a sizeable catchment. The river starts as a series of small streams up in the Jinma Ranges, an area of cattle country a couple of hours drive inland from the coast; these join two main branches which come down through several large storage dams which supply Brisbane and much of the surrounding area, into the farming valleys north of Ipswich. It then winds in big loops across the rich floodplain that made Brisbane an ideal site for early agricultural settlement. The city itself is much shaped by the river, both physically and in terms of its identity as 'The River City'. Brisbane is also greatly influenced by its role as a major port, from which shipping transports the goods produced in the river catchment to Australia's trading partners. The journey of the river itself is therefore also a metaphor of the process of acculturation, as it flows out of the more loosely managed environment of cattle farming and recreational land use, in which many natural ecological processes continue, through the more heavily manipulated landscapes of industrial farming, and into the intensive urban development of the city itself.

It is useful to consider the ways in which the river is transformed along the way. In the relatively undisturbed environment of the Jinma peaks the river starts in small streams and muddy waterholes that are shared by kangaroos and cattle alike, filling rapidly in the wet, and disappearing in the dry. Homesteads and cattle wells rely on a scattering of bores to pump streams of water into drinking troughs so that cattle have a reliable year round supply. Thus in its upper catchment, the Brisbane River's major contribution to human activity is simply to provide water and feed for the cattle who, from the perspective of their owners, convert it into 'beef'. The upper river therefore supports the type of 'primary 
production' that for most of Queensland's colonial history was a central plank in its economic practices, empowering a powerful landowning squattocracy. A few remnants of this elite remain up in the hills here, busily fending off efforts by the State Government to challenge or share their control of the land and its management.

Below the ranges the river is captured in the Somerset and Wivenhoe dams. There is a dual purpose here: one, ostensibly, to control the flow of the river and thus prevent the kinds of massive floods that devastated Brisbane in 1893 and $1974 .{ }^{13}$ Their major purpose, though, is to store water and provide a dependable domestic and industrial water supply. Thus, although the water is simply contained, and the treatment that ensures it is potable takes place further downstream, it is at this point that the river undergoes its first major physical and categorical transformation from being merely 'part of the natural ecosystem' into the vital commercial resource of 'water supply'. This process is physically controlled by Sunwater, which transports the water (thus converting it into cash flow), and governed by its major customer and shareholder, Brisbane City Council, which gains a large and reliable income by selling the water to the city's inhabitants. Thus the water held in the dams represents not only the potential for all the transformations that take place downstream, it is also a more abstract 'pool' of resources for the city and its governing agencies.

Below the dams, the Brisbane River flows into Queensland's 'vegetable and fruit bowl'. This description reflects the fact that in this area, with its good soils and sunny climate, it has been possible to grow just about anything: grapes, carrots, water melons, pineapples, broccoli and so on, all of which come to fruition well before crops produced in the cooler Australian south. Here the water is taken much more physically 'in hand': sucked into pipes, pushed into irrigation channels, and sprayed onto fields in whirling artificial fountains. Absorbed into the thirsty crops, it becomes all manner of 'produce', which is harvested, marketed and, more often than not, packed into the containers awaiting shipment down in Brisbane's port. Thus, taken into the material control of the rural 'producers', it becomes whatever crop they choose to farm, applying their knowledge and skill to

\footnotetext{
${ }^{13}$ Flood prevention provided the major rationale for the construction of the Wivenhoe Dam, but although this has recently been enlarged, it is a reality that it would only spare the city from being inundated if the rain fell in particular areas, and might do little to ameliorate the effects of extreme rainfall in other parts of the catchment.
} 
transform soil, water and seed into the agri-culture that defines who they are. Like the cattle farmers, this is a group that has long held considerable status as providers of the wider population's most fundamental needs, but now senses a crucial loss of status and influence. And again like the graziers, the fruit and vegetable growers feel beleaguered by the expansion of the city and its greedy search for recreational space, lifestyle blocks and room for development.

Further downstream the river is transformed into a host of much more complicated objects as it becomes a vital component of industrial production. Brisbane has many concrete works, tanneries, timber mills and chemical factories, all of which produce artefacts that are dependent in one way or another on water. Each industry - directly or indirectly - depends upon the flowing river, taking and shaping its water in a particular series of conversions through which it becomes an array of material culture: for example, paint, soft drinks, garden plants, leather and wine. For each of these industries, these commercial 'products' are the objects through which particular networks of people enact a social identity. This is often articulated through the formation of industry groups, ${ }^{14}$ whose purpose is to forward and protect the interests of particular social and economic networks. These industryspecific networks meet and mesh, overlap and entangle more generally, forming the South Queensland 'business community' which, although it has many disparate and not always harmonious parts, shares a common goal of industrial 'production'. This community is the local base for the trading links through which goods and services flow, often through the mouth of the river, between South Queensland and a wider national and international social, economic and political context.

The other major social and political force in Brisbane is provided by the range of organisations and agencies through which State and local governance is arranged. As noted previously, it is the control of regional water resources that provides Brisbane City Council's most reliable source of funds, and in this sense it converts water into a host of other more ephemeral resources: education, health, law and order, administration, and so on. More materially, it makes considerable use of water supplies itself, to maintain the

\footnotetext{
${ }^{14}$ For example, the Extractive Industries Association, the Wine Industry Association, the Seafood Industry Association, and the Boating Industry Association.
} 
physical environment within the city. And within this environment, of course, there are also several million domestic water users, who convert the supplies pumped to their dwellings into physical health, energy and cleanliness, as well as green lawns and decorative water features whose purpose is purely aesthetic.

This relates to another major use of water, and of the river. As the Brisbane River flows down from the ranges, and is siphoned off into these many forms of production, it also becomes an object of aesthetic pleasure and social status to wealthy riverside homes and 'lifestyle blocks', and a source of recreational pleasure to many of the city's inhabitants. People have always used the river recreationally, swimming and fishing in it, boating on it, and picnicking beside it, but in recent decades this type of usage has increased considerably. This is partly due to the rapid expansion of the city - over 1500 people moved there every week in 2004. People are more affluent, and have the cars, boats and leisure time to make much fuller use of the aquatic environment. And the population as a whole has become more urban, and keen to use green space recreationally.

This changing engagement with the river has also led to another critical form of commodification as it has become the plaything upon which many recreational enterprises rely. In the last decade or so, the tourist industry in Brisbane has boomed, commensurately increasing the extent to which water is seen as something that, rather than producing material objects, offers more ephemeral things, such as relaxation, pleasure and entertainment, for consumption. In economic terms this has produced a shift from dependency on primary production to industries whose interests lie in having access to an unpolluted 'natural' environment. Thus, rather than extracting water from the river in order to convert it into beef, wine and vegetables, these industries are concerned with commodifying it in situ, along with the rest of the landscape. And although tourism is often presented as a more benign form of resource use - and can certainly be said to have less physical impact than many forms of farming or resource extraction - it represents, in some ways, a much more wholescale commodification, in which the landscape, the ecosystem as a whole, is recast as a recreational object. 
These socio-economic shifts are intensely threatening to the farming community. The relative profitability of these secondary industries has superseded the farmers' contribution to the State economy and thus given greater power and influence to non-primary producers who are based in urban areas. It is difficult for farmers not to feel considerable resentment towards an urban population that wants cheap food, and refuses to assign greater value to the rural industries, and then - insult to injury - wants to make recreational use of land that farmers regard as their private space. Not only that, but these urban dwellers use water so profligately that, in times of drought, farmers are sometimes deprived of the allocations that enable them to produce anything at all.

Clearly there are many basic reasons why conflicts over the control and use of water arise: however, to understand why these conflicts are so emotive, it is useful to examine the process through which water is transformed. Water is vital to farmers in two ways. Firstly, they have to imbibe it in order to maintain their own physical constitution - it is, quite literally their essence and their identity: the substance of which they are physically composed, and which links them literally and imaginatively to the environment that they inhabit. In addition, through their work - their actions, their labour and their time - they feed water into the things that become the product of this work. The use of the same fluid to both make and express the self is a powerful conjunction, which greatly strengthens the farmers' identification with the 'commodities' that they produce, and with the landscapes in which this transformation takes place.

Considered from this point of view, we can see that competition for water resources isn't just an economic issue in which farmers' livelihoods are compromised, it is also to do with a much deeper threat to their ability to express their social identity as primary producers. The things that they transform water into are, as Gell would have it, ${ }^{15}$ extensions of themselves: the material expression of their productive and indeed reproductive abilities. To lose their water allocations, to be blocked from action by pressure to leave the environment as a pristine recreational space, emasculates their potential to generate and reproduce their social being and identity and to create wealth and status.

\footnotetext{
${ }^{15}$ Gell (1998).
} 
Similarly, to have their private landscapes appropriated and invaded by recreational land and water users, strangers from outside their own community, represents a meaningful loss of control, a breaching of boundaries with a polluting influx of 'otherness'. And because of the close co-identification that the farmers have with the substances that are integral both to their own bodies and to the organic products of their labour, this incursion is felt particularly deeply.

This provides some insight into the meanings of water that contribute greatly to the tensions between rural and urban communities. Broadly speaking, in the Brisbane River catchment area, there are the rural producers, trying to defend their intimate, deeply rooted environmental interaction and maintain their generative capacity at all levels. There are urban dwellers who, feeling their severance from the wider material landscape, are keen to re-establish a connection with it through aesthetic and sensory engagements that allow them to experience and know that landscape, to express themselves in it creatively, and thus to identify with it as well. There are the burgeoning industries who want to turn water into an array of material objects, and the recreational industries and environmental groups who want to ensure that the ecological capacities of the environment are not compromised. Then there are the government agencies charged with meeting or at least balancing the needs of all of these different constituencies. This is fast becoming an impossible task: each group involved with the river wants to convert it to its own use, but with a growing population and insufficient water to meet all of these demands, the question of whose claims are prioritised can only become increasingly contested.

Clearly there are no miraculous answers to this problem, but some understanding of the underlying complexities, and some insights into the reasons why the control of water is such an emotive issue, may help to resolve some of the emerging conflicts.

\section{References}

Appadurai, A. (1986) The Social Life of Things. Cambridge: Cambridge University Press.

Atran, S. (1990) Cognitive Foundations of Natural History, Cambridge, New York: Cambridge University Press. 
Bender, B. (ed) (1993) Landscape, politics and perspectives. Oxford: Berg.

Bennett, V. (1995) The Politics of Water: urban protest, gender and power in Monterrey, Mexico. Pittsburgh and London: University of Pittsburgh Press.

Blatter, J. \& Ingram, H. (2001) (eds.) Reflections on Water: new approaches to transboundary conflicts and cooperation. Cambridge, Mass., London: MIT Press.

Caplan, P. (ed.) (1997) Food, Health and Identity. London, New York: Routledge.

Carrier, J. (1995) Gifts and Commodities, London: Routledge.

Csikzentmihalyi, M. \& Rochberg-Halton, E. (1981) The Meaning of Things: domestic symbols and the self, Cambridge, London, New York, New Rochelle, Melbourne, Sydney: Cambridge University Press.

Douglas, M. (1975) Implicit Meanings: essays in anthropology, London, Boston, Melbourne and Henley: Routledge and Kegan Paul.

Durkheim, É. (1995 [1912]) The Elementary Forms of the Religious Life, trans. K. Fields, New York: Free Press.

Gell, A. (1998) Art and Agency: an anthropological theory, Oxford: Clarendon Press.

Hegel, F. (1977) The Phenomenology of Spirit. Oxford: Clarendon Press.

Howes, D. (2003) Sensual Relations: engaging the senses in culture and social theory. Ann Arbor: University of Michigan Press.

Kopytoff, I. (1986) "The Cultural Biography of Things: commoditization as process" in A. Appadurai (ed) The Social Life of Things: commodities in cultural perspective. Cambridge: Cambridge University Press.

Lansing, S. (1991) Priests and Programmers: technologies of power in the engineered landscape of Bali, Princeton, New Jersey: Princeton University Press.

Lupton, D. (1996) Food, the Body and the Self. London, Thousand Oaks, New Delhi: Sage Publications.

Miller, D. (ed.) (1998) Material Cultures: why some things matter. London: UCL Press.

Schechner, R. (1985) Between Theatre and Anthropology, Philadelphia: University of Pennsylvania Press.

Shore, B. (1996) Culture in Mind: cognition, culture and the problem of meaning, New York, Oxford: Oxford University Press.

Stewart, P. \& Strathern, A. (eds.) (2003) Landscape, Memory and History, London: Pluto Press.

Strang, V. (1997) Uncommon Ground; cultural landscapes and environmental values, Oxford, New York: Berg. 
(1999) "Familiar Forms: Homologues, Culture and Gender in Northern Australia", Journal of the Royal Anthropological Society, 5(1):75-95.

- (2001) "Negotiating the River: Cultural Tributaries in Far North Queensland", in B. Bender \& M. Winer (eds.) Contested Landscapes: Movement, Exile and Place, Oxford, New York: Berg.

(2002) "Life Down Under: Water and Identity in an Aboriginal Cultural Landscape", Goldsmiths College Anthropology Research Papers. No. 7. London: Goldsmiths College.

— (2004) The Meaning of Water, Oxford, New York: Berg.

(2005a) "Knowing Me, Knowing You: Aboriginal and Euro-Australian Concepts of Nature as Self and Other", World Views: Environment, Culture, Religion, 9(1):25-56.

(2005b) "Common Senses: Water, Sensory Experience and the Generation of Meaning", Journal of Material Culture 10(1): 93-121.

— (2005c) "Water Works: Agency and Creativity in the Mitchell River Catchment", The Australian Journal of Anthropology, 16(3): 366-81.

Tilley, C. (1994) A Phenomenology of Landscape: places, paths and monument, Oxford, Providence: Berg.

— (1999) (ed.) Metaphor and Material Culture, Oxford: Blackwells.

Turner, V. (1982) From Ritual to Theatre: the human seriousness of play, New York: Performing Arts Journal Publications.

Ward, C. (1997) Reflected in Water: a crisis in social responsibility, London and Washington: Cassell. 